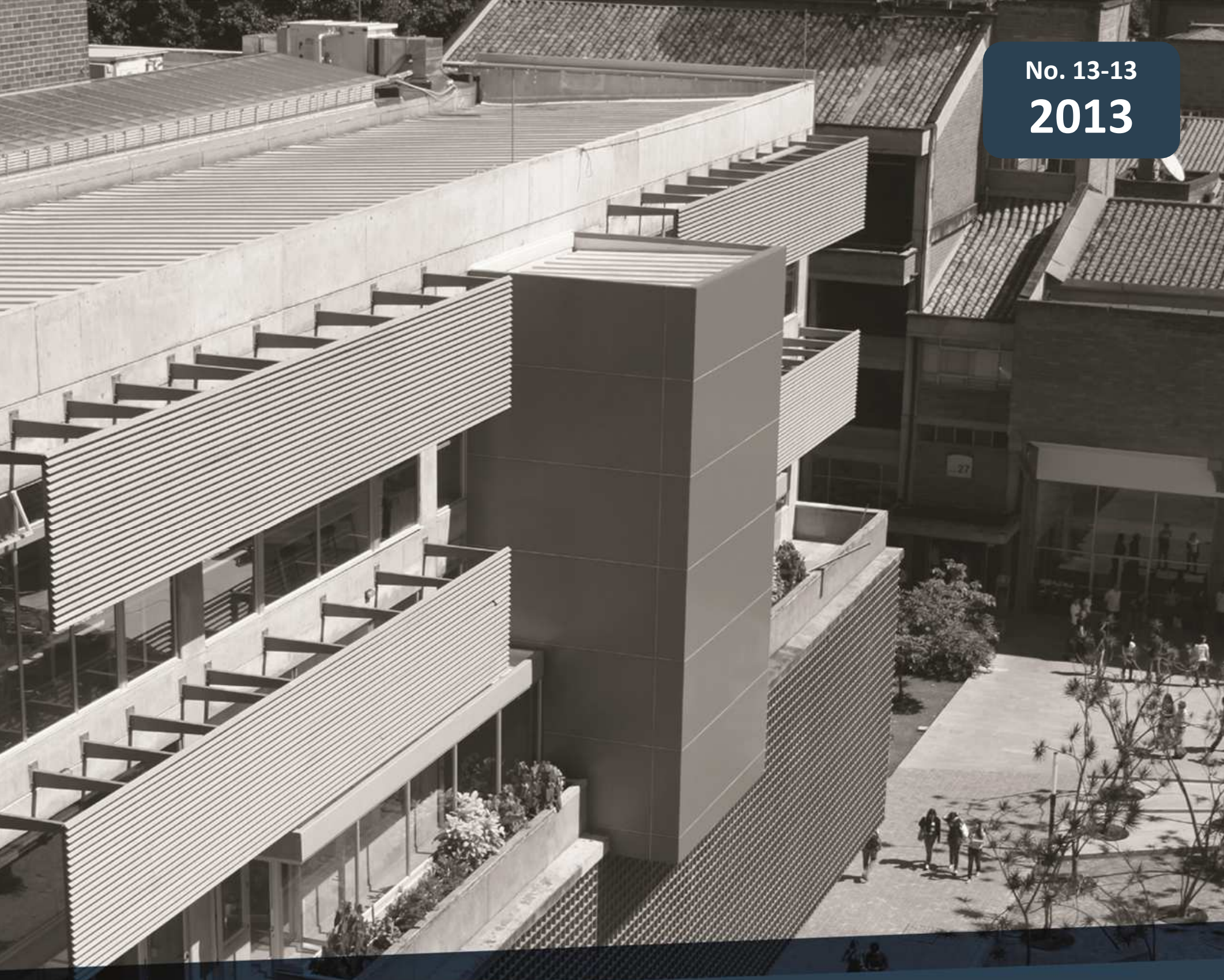

VOLATILITY AND GROWTH: AN EXPLANATION FOR THE DISAGREEMENT Michael Jetter

Documentos de trabajo Economía y Finanzas

Centro de Investigaciones Económicas y Financieras (CIEF)

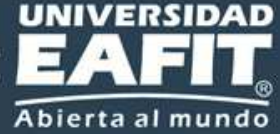




\title{
Volatility and Growth: An Explanation for the Disagreement*
}

\author{
Michael Jetter ${ }^{\dagger}$
}

June 26, 2013

\begin{abstract}
This paper reconsiders the effects of volatile growth rates on growth itself. I show that the underlying endogeneity of government size can hide the net growth effects from volatility. There exists a positive direct and a negative indirect channel, with the latter operating through the size of the public sector. Risk-averse citizens respond to volatility either with precautionary savings (direct effect) or by demanding a stronger public safety net, which in turn lowers growth (indirect effect). However, the indirect channel is only available if the political regime allows citizens to determine their desired level of public services. I test this theory on a balanced panel of 95 countries from $1960-2010$. The paper reveals the latent endogeneity of government size in a single growth equation framework and offers a simultaneous estimation method as an alternative. Results support the existence of both effects. The direct channel is stronger in autocratic societies, but as a country turns to democracy the indirect channel dominates. Volatility has a positive net effect on growth in autocratic nations, but a negative net effect in democratic societies. This finding explains why previous growth analyses of volatility at times reached contradicting conclusions.
\end{abstract}

JEL Classification: E32, H11, O40

Keywords: Volatility, Business Cycles, Economic Growth

${ }^{*}$ I am thankful to Alejandra Montoya Agudelo for excellent research assistance. I am also grateful to Jean Imbs and Andrés Ramírez Hassan for fruitful discussions. All remaining errors are my own.

${ }^{\dagger}$ Department of Economics, School of Economics and Finance, Universidad EAFIT, Carrera 49 \#7 Sur50, Avenida Las Vegas, Medellín, Colombia; phone: +57.317.433.7003; email: mjetter7@gmail.com; web: www. michaeljetter.com 


\section{Introduction}

As most countries are trying to recover from the Global Financial Crisis of 2007/2008, the connection between macroeconomic volatility and economic growth has gained even more importance than before, if this was even possible. Latest since Ramey and Ramey (1995) proposed an intimate relationship between business cycles and growth rates, various sorts of volatility have been analyzed in this context. ${ }^{1}$ One can find a variety of results, covering the complete range of positive, negative, or no effects from volatility on growth. ${ }^{2}$

This paper suggests two distinct channels in which volatility affects growth on the macroeconomic level. Confronted with a volatile economy, risk-averse citizens may consider two main options to insure themselves: (1) raise precautionary savings or (2) demand a stronger public safety net from the government. The former effect goes back as far as Mirman (1971) and is akin to Devereux and Smith (1994), where reduced savings lower growth. The latter channel implies bigger governments in volatile times (see Rodrik, 1998, which may in turn lower growth rates in the short run, as resources are being withdrawn from the private sector (see Barro and Lee, 1994, Barro, 2001, or Afonso and Furceri, 2010). ${ }^{3}$ Thus, there could be a positive direct and a negative indirect effect of volatility on growth. In theory, the net effect could then be ambiguous, as the mechanisms are pulling in opposite directions.

The following pages first show that ignoring the underlying endogeneity of government size, as well as the role of the political regime, can lead to misleading conclusions. After addressing the suggested endogeneity of government size in a simultaneous estimation setup, both the positive direct and the negative indirect effect are highly significant. However, the occurrence

\footnotetext{
${ }^{1}$ See for example Devereux and Smith (1994), Ayhan Kose et al. (2005), Norrbin and Pinar Yigit (2005), or Imbs (2007).

${ }^{2}$ Döpke (2004) provides an excellent discussion of the literature. Some papers confirming Ramey and Ramey (1995) in suggesting negative growth effects from volatility are Wang and Wen (2011), Furceri (2010), or Badinger (2010), whereas others (Oikawa, 2010, Canton, 2002, Caporale and McKiernan, 1998, or Devereux and Smith, 1994) find volatility to spur growth. Posch and Wälde (2011) or Dawson and Stephenson (1997) further suggest that there exists no link at all between output volatility and growth. Finally, other papers (e.g. Aghion et al., 2010, Imbs, 2007, or Imbs, 2002) argue that volatility and growth could be related in various ways, some of which could operate in opposite directions.

${ }^{3}$ Jetter et al. (2013) formalize this idea in the context of labor market choices and wage volatility. Rodrik (1998) famously introduces the thought that risk-averse citizens demand stronger social safety nets. There is an extensive discussion surrounding this theory, as Rodrik (1998) first relates openness to trade to uncertainty, which then in turn raises the demand for public goods by risk-averse citizens. In this chain of arguments, the first link of openness leading to more volatility is heavily debated. The present paper only builds on the second effect of volatility causing people to demand more security from the public sector.
} 
of both effects varies substantially across countries. Especially the second option of demanding government services relies on the citizen's option to engage in the political process. Citizens can only actively influence public goods provision if they have a say in politics. Indeed, the positive direct effect dominates in autocratic regimes, whereas the negative indirect effect is absent. Once a country evolves into a democratic society the indirect channel gains importance and eventually dominates the direct channel. Thus, people eventually seem to choose an increase in public insurance over precautionary savings as a response to volatility.

This result provides an explanation why previous analyses could not agree on the net effect of volatility on growth. Depending on the sample at hand, a single estimation framework can produce positive, negative, or no net effects on growth. One needs to take into account the political regime and the underlying endogeneity of government size. Both characteristics are important when evaluating potential consequences from policies affecting the business cycle. Further, these findings may explain why some papers (most prominently Ramey and Ramey, 1995 and later Martin and Ann Rogers, 2000) find strong negative growth effects of volatility especially in OECD economies, as these countries are mostly democratic and tend to have bigger governments. Finally, this result emphasizes the importance of non-linearities in the growth literature, in this case along the lines of political regime and government size for the effects from volatility.

The paper proceeds with section 2 laying out the methodological setup. Section 3 describes the sample and section 4 presents the empirical findings. Finally, section 5 concludes.

\section{Methodology}

As there exists an open-ended list of potential growth determinants, I use two main reference papers to set up a growth regression framework: the variables from Levine and Renelt (1992) and more recently Mirestean and Tsangarides (2009). In addition, the empirical analysis includes country fixed effects and country specific time trends, accounting for the unique characteristics in terms of history, geography, climate, and development paths of every country.

\footnotetext{
${ }^{4}$ Recently, several nonlinearities have been pointed out in the growth literature, such as Reinhart and Rogoff (2010) considering public debt or Henderson et al. (2012) in the context of financial development. In a related context, Cohen-Cole et al. (2012) revisit the link between foreign aid and the quality of policy in the recipient country.
} 


\subsection{OLS Estimation}

The empirical section starts by estimating growth in a single-estimation framework for country $i$ at year $t$, including the volatility of economic growth:

$$
g r_{i, t}=\alpha_{1}+\alpha_{2} \operatorname{vol}_{i, t-1}+\alpha_{3} \operatorname{lngov}_{i, t}+\alpha_{4} g r_{i, t-1}+\alpha_{5} X_{i, t-1}+\alpha_{6} \lambda_{i}+\alpha_{7} \phi_{i, t}+\delta_{i, t},
$$

where $\operatorname{vol}_{i, t-1}$ stands for growth volatility (calculation explained below). Further, $\operatorname{lng}_{i, t}$ represents government size and $g r_{i, t-1}$ captures the growth rate of the previous year. $X_{i, t-1}$ contains growth determinants suggested by Levine and Renelt (1992) and Mirestean and Tsangarides (2009). Specifically, $X_{i, t-1}$ contains investment (lninv), income (lngdp), population growth (popgr), life expectancy (lnlife), openness to trade (lnopen), and inflation (lninfl). ${ }^{5}$ Absent from the Levine and Renelt data set is only initial human capital, which in a panel setting with fixed effects and country-specific time trends may lose importance anyways. ${ }^{6}$ From Mirestean and Tsangarides (2009), I am not including public debt, as missing data would reduce the sample by over 85 percent. Finally, $\lambda_{i}$ and $\phi_{i, t}$ introduce country fixed effects and country-specific time trends, whereas $\delta_{i, t}$ stands for the usual error term. In order to address the latent reverse causality problem of the growth literature, vol and $X$ are lagged by one year, following suggestions by Temple (1999) and Durlauf et al. (2005) among others.

\subsection{Estimating Volatility}

A crucial aspect of this analysis is how to calculate volatility. For instance, Ramey and Ramey (1995) choose the standard deviation of a country's growth rates over time. However, the problem of this method is that one is stuck with a single observation per country or at least fewer observations if one decides to split the sample. Recently, several filters have become prominent in detrending macroeconomic time series, such as the Hodrick-Prescott (HP) filter. For instance, Ravn and Uhlig (2002) state that “...the HP filter has become a standard method for removing trend movements in the business cycle literature." Although the filter has been

\footnotetext{
${ }^{5}$ Variables starting with $\ln$ imply the application of the natural logarithm.

${ }^{6}$ This goes along with the more practical reason that annual or even frequent data on human capital is difficult to come by.
} 
subject to heavy criticism, it "has withstood the test of time and the fire of discussion relatively well." Further: "One attraction of the HP filter is that it may be applied to nonstationary time series (series containing one or more unit roots in their autoregressive representation), a relevant concern for many macroeconomic and financial time series."

Thus, I use the HP filter to detrend every country's growth rate, applying the benchmark value of $\lambda_{H P}=100$ when using annual time series data to adjust for the sensitivity of the trend portion. ${ }^{7}$ As I am only using countries for which all growth rates are available from 1960 - 2010, each time series contains 51 data points. The result from applying the HP filter is an annual cycle term for each country. As we are interested in business cycles in general, I square this value to obtain a measurement for the annual volatility component of a country's growth rate. ${ }^{8}$ Finally, I divide this value by 100 in order to facilitate comparability in regressions to obtain $\operatorname{vol}_{i, t-1}$.

\section{$2.3 \quad 3$ SLS Estimation}

After estimating equation 1, the empirical section presents evidence for the inconsistency of a simultaneous estimation framework, as the Durbin-Wu-Hausman test statistics (see Davidson and MacKinnon, 2001) confirms the endogeneity of government size. The paper then moves to a three-stage least squares (3SLS) estimation system, where growth and government size are determined simultaneously. Specifically, the government size regression takes the following form:

$$
\operatorname{lngov}_{i, t}=\beta_{1}+\beta_{2} \operatorname{vol}_{i, t-1}+\beta_{3} g_{i, t}+\beta_{4} \operatorname{lngov}_{i, t-1}+\beta_{5} Z_{i, t-1}+\beta_{6} \lambda_{i}+\beta_{7} \phi_{i, t}+\epsilon_{i, t},
$$

where $\operatorname{lngov}_{i, t-1}$ takes into account government size of the previous year and $Z_{i, t-1}$ is a vector containing the usual control variables of the literature, as summarized by Shelton (2007). Among these are income $(\operatorname{lng} d p)$, openness to trade (lnopen), and population size (lnpop). As in the growth regression, I choose lagged explanatory variables, both for consistency and in order to address potential effects from government size on openness and GDP, for instance. Further,

\footnotetext{
${ }^{7}$ For the choice of the HP filter in this context, see for instance Döpke (2004) or Mills (2000). Using $\lambda_{H P}=100$ for annual time series goes back to Backus and Kehoe (1992) among others. Section 4.4 provides alternatives.

${ }^{8}$ This procedure follows Jetter et al. (2013).
} 
using lagged volatility reduces potential issues from reverse causality, as future government size is unlikely to affect the explanatory variables today. ${ }^{9}$ In fact, given that the political process usually takes its time, we might expect a slightly delayed reaction time in general for most government size determinants.

Both equations 1 and 2 are identified by unique variables. For the growth regression, these are lagged growth, investment, population growth, inflation, and life expectancy. In the case of government size, these are lagged government size and total population size. Their suitability as identifying variables is comfortably validated by F-tests for joint insignificance of the unique dependent variables in all respective regressions (not displayed). Finally, incorporating the seemingly unrelated regression equations model (SUR) accounts for potential correlation of the error terms.

\section{Data}

All variables are displayed in table 1 and are taken from one of three standard data sources in macroeconomics: the World Bank Development Indicators, the Penn World Table Version 7.1, and the Polity IV index. On average, the 95 sample countries had an annual growth rate of almost 4 percent. Table 2 sorts all sample countries by their average yearly volatility over the entire time span of 1960 - 2010. We notice that the core European countries, together with South Africa, Sri Lanka, Australia, Guatemala, and Colombia, had low growth volatility since 1960. Various African (such as Liberia, the Seychelles, or Rwanda) and some Asian economies (e.g. the Oman) on the other hand experienced many twists and turns. ${ }^{10}$

Further, figure 1 shows the worldwide average volatility over time and a breakdown by continents. We notice major spikes in the mid 60 s and the late $90 \mathrm{~s}$, where the former appears to be driven by African, Asian, and European economies. In general, Asian countries managed to tame their business cycles since the mid 1970s, whereas African nations on average continue to incur strongly volatile periods. Noteworthy is also a comparison between the richest nations, as cycles generally appear more prevalent in North America with the oil crisis in the early 70s

\footnotetext{
${ }^{9}$ See for instance Acemoglu et al. (2003) or Klomp and de Haan (2009) for the argument of institutions in general influencing volatility.

${ }^{10}$ See Koren and Tenreyro (2007) for an explanation of why poor countries might have more volatility than rich ones.
} 
standing out. Finally, the 2007 global financial crisis is especially visible in the Americas and Europe, as for the average European country volatility reached its highest level since the mid 60 s.

\section{Empirical Results}

\subsection{OLS Results}

Table 3 displays the results from the generic growth regression of equation 1, gradually adding explanatory variables. Column (1) starts with the most basic model, only using volatility and the growth rate of the previous year as regressors. Columns (2) and (3) add country fixed effects and country time trends, accounting for the individual characteristics of each country. Specification (4) adds government size as a regressor, following Barro and Lee (1994) and others. Finally, (5) and (6) add the growth determinants used by Levine and Renelt (1992) and Mirestean and Tsangarides (2009).

As for the coefficient of interest, we see only weak evidence for the importance of volatility. The coefficient on $v o l$ is mostly positive, but insignificant in all specifications (although close to the ten percent significance threshold level in the final specifications). The coefficients on the other control variables (not displayed) generally confirm the existing opinions in the literature. ${ }^{11}$ Were one to stop here, the conclusion would be that either the business cycle does not affect economic growth at all or that there exists a weak positive relationship. A close look reveals that including government size in column (4) changes the coefficient on volatility remarkably, suggesting potential problems of endogeneity. In fact, running the Durbin-Wu-Hausman (DWH) test reveals that the regressions are problematic and government size is endogenous. The significance of the F-values, displayed at the bottom of each regression, indicates that OLS is not consistent. ${ }^{12}$ I will turn back to the endogeneity problem in section 4.2 by estimating growth and government size simultaneously.

Table 4 splits the sample in two types of observations: countries with autocratic and demo-

\footnotetext{
${ }^{11}$ Investment, life expectancy, and openness to trade have positive and significant effects on growth, whereas income and inflation (weakly) carry negative growth effects.

${ }^{12}$ In estimating government size, I include lagged government size, openness to trade, GDP, and population size (all in logs), following Shelton (2007).
} 
cratic regimes. I replicate columns (4) - (6) from table 3 once for observations where a polity score is negative and then for positive polity values. Specifically, I use the polity 2 variable, designed for regression analysis with values ranging from -10 (totally autocratic) to +10 (totally democratic). Comparing the regression coefficients reveals an interesting difference as volatility seems to have a strong positive effect in autocratic regimes, but is insignificant in democracies. In all specifications, the DWH test for endogeneity is strongly significant, pointing out problems with a single estimation framework. With the intuition of both a direct and an indirect effect in mind (and the endogeneity of government size confirmed), I now turn to a simultaneous estimation framework.

\subsection{SLS Results}

Table 5 shows regressions from estimating growth and government size simultaneously. ${ }^{13}$ Columns (1) and (2) use the entire sample and we notice a remarkable difference to the OLS framework above. The intuition on the existence of two distinct channels - a positive direct and a negative indirect effect - is confirmed: volatility is strongly positive and significant in the growth regression, but it also affects government size positively, which in turn has a negative effect on growth.

Column (3) then only considers countries, which at the time of observation are marked with a negative polity score (autocratic regimes). The positive direct effect is strengthened with its significance level rising to the one percent level and its magnitude increasing by over 50 percent. However, volatility does not seem to affect government size in autocracies. This result seems quite intuitive as options to influence the provision and extent of public services is by definition limited in autocratic regimes.

Column (4) considers democratic regimes with a positive polity score. Results are reversed as the positive direct effect turns insignificant and reduces to almost a third of its original magnitude from column (2), whereas volatility raises government size. This provides evidence of a shift in response to volatility shocks, depending on the political regime: in autocracies

\footnotetext{
${ }^{13}$ Similar to the growth regressions, the remaining government size determinants generally confirm the conventional conclusions in the corresponding literature: bigger populations seem to have smaller governments (see Alesina and Wacziarg, 1998), plus I find mixed evidence for the effect from openness to trade (a relationship heavily discussed since Rodrik, 1998). These results are not displayed due to lack of space, but available upon request.
} 
people seem to use precautionary savings, whereas in democracies people preferably turn to the government, demanding a more defined provision of public services as an insurance.

One downfall of this analysis is the arbitrary distinction into positive and negative values of polity. Thus, column (5) uses the entire sample, including an interaction term between volatility and the polity score in both regressions. We note that the interaction term is negative and significant in determining growth, but positive and significant in determining government size. Thus, as the democratic system rises, the direct effect of volatility on growth diminishes, but the indirect effect gains importance. ${ }^{14}$ Following the final and most complete specification of column (5), a one standard deviation of volatility is suggested to lower the growth rate of GDP by 0.85 percentage points in a country with a perfect polity score of $10{ }^{15}$ On the other end of the spectrum, a totally autocratic regime (polity score of -10) would enjoy an increase in the rate of economic growth by 1.08 percentage points.

\subsection{Development Over Time and Country Examples}

In fact, the results suggest a threshold combination of a country's polity score and its size of government over (under) which the net effect of volatility on growth is negative (positive). ${ }^{16}$ Generally speaking, with more democracy and bigger governments comes a negative net effect from volatility on growth. Figure 2 provides several snapshots of the sample data, with the solid line representing the threshold level. We see that over time countries have moved towards democracies (further up in the graph) and bigger governments (further to the right). Both developments eventually lead to negative growth effects from volatility, although the impact of the regime form is substantially stronger than the impact of government size. The graphs show that countries have started to move towards democratic systems especially since the late 80s.

Figure 2 also displays several sample countries with their combinations of political regime form and government size over time. On the one extreme, the United States represent a country, which exclusively received the high score of 10 on the polity scale, translating into negative net

\footnotetext{
${ }^{14}$ Including an interaction term of government size with polity in the growth regression did not produce significant results. Thus, I do not find evidence that the negative effect of government size on growth varies by level of democracy.

${ }^{15}$ Calculation: $\Delta g r=1.87[0.329-10 \times 0.074-1.439(0.012+10 \times 0.002)]$.

${ }^{16}$ Calculation: $0.329-0.074 \times$ polity $-1.439 \times \operatorname{lngov}(0.012+$ polity $\times 0.002)=0$, which leads to polity $=$ $\frac{0.329-1.439 \times \operatorname{lngov} \times 0.012}{1.439 \times 0.002 \times \ln \text { gov }+0.074}$.
} 
effects from volatility throughout the entire sample period since 1961 . The other extreme is represented by Oman, one of the most autocratic countries on earth, according to the polity score. Here, volatility should have exclusively contributed positively to growth. Countries where we observe both scenarios over time include Spain, Brazil, Thailand, or Ghana.

Using Spain as an example, a closer look at the data suggests that a period of relatively high volatility in the early 1970s spurred growth, as their polity score was -7 under the dictatorship of Franco. High volatility in the late 80s and early 90s, as well as in 2009, however had negative growth effects, as the country was considered a perfect democracy with a score of 10. Similarly, Brazil seemed to have benefitted from high volatility in the early 80 s, but then volatility should have had negative growth effects in the late $80 \mathrm{~s}$, as its political regime changed drastically towards a democracy around 1985 with the "New Republic."

\subsection{Robustness Checks}

This section presents several alternative specifications, addressing the value of $\lambda_{H P}$ in the Hodrick-Prescott (HP) filter, the end of sample problem in the application of the HP filter, and the definition of government size. Table 6 displays the results of replicating the two main specifications (2) and (5) from table 5 for each robustness check.

First, the benchmark value of $\lambda_{H P}=100$ for annual data has been subject to criticism in the econometrics literature, where most notably Ravn and Uhlig (2002) suggest a value of $\lambda_{H P}=6.25$. Columns (1) and (2) in table 6 show the results when detrending growth rates with $\lambda_{H P}=6.25$. The general implications of the main results are confirmed, as we observe both a positive direct and negative indirect effect, where the polity score plays the same role as before: autocracies (democracies) tend to have positive (negative) net effects. Even though signs and

significance levels (mostly) confirm the previous findings, magnitudes are lower, which might be due to the fact that with smaller $\lambda_{H P}$ comes a smaller penalty for variations in the growth rate, i.e. the "trend" is given more flexibility.

Second, there exists another criticism of the HP filter: the end of sample problem (see Watson, 2007). With a balanced sample of 51 observations per country, specifications (3) and (4) in table 6 re-estimate the simultaneously determined equations, only now cutting off the first and final five years of the sample. This means that the volatility term is still estimated using 
the entire 51 years per country, but only the 41 years in the middle are used for regressions. A look at the results reveals no change in significance levels and only minor deviations in terms of magnitudes.

Finally, specifications (5) and (6) check whether the results are robust to using shares of government spending and investment in GDP. In the main estimations, I use total government spending and total investment. We notice that the direct effect remains positive and significant, yet the indirect effect turns negative and insignificant in column (5). However, including the interaction with the polity score in column (6) recovers the main result from above. Notice that switching to shares changes the numerical interpretation of the coefficients associated with government size.

\section{Conclusion}

This paper suggests two distinct macroeconomic channels through which volatile growth rates affect growth in the short run. Assembling singular findings in the respective literatures suggests a positive direct and a negative indirect effect of volatility on growth. One explanation could be that risk-averse citizens have two options of responding to volatility: raising precautionary savings or demanding public services for insurance. The former has a positive direct effect on growth, whereas in the latter volatility increases the size of the public sector, which in turn has a negative effect on growth in the short run.

Whether volatility has positive or negative net effects on growth then depends mostly on the level of democracy, but also (to a lesser degree) on government size. In autocratic regimes, the indirect channel is closed, as people do not have the political power to determine their desired level of public services. The more democratic a country, the more likely it is that volatility carries negative net growth effects. In fact, the empirical estimates suggest that a one standard deviation of growth volatility may lower (raise) the growth rate by 0.85 (1.08) percentage points in a perfect democracy (autocracy).

In general, this paper strengthens the argument that business cycles do matter in the growth context. However, the implementation of policies aimed at limiting or unleashing volatility should consider both the political regime of a country and the size of its public sector, if one is 
concerned about economic growth in the short run.

\section{References}

Acemoglu, D., Johnson, S., Robinson, J., and Thaicharoen, Y. (2003). Institutional causes, macroeconomic symptoms: Volatility, crises and growth. Journal of Monetary Economics, 50(1):49-123.

Afonso, A. and Furceri, D. (2010). Government size, composition, volatility and economic growth. European Journal of Political Economy, 26(4):517-532.

Aghion, P., Angeletos, G.-M., Banerjee, A., and Manova, K. (2010). Volatility and growth: Credit constraints and the composition of investment. Journal of Monetary Economics, $57(3): 246-265$.

Alesina, A. and Wacziarg, R. (1998). Openness, country size and government. Journal of Public Economics, 69(3):305-321.

Ayhan Kose, M., Prasad, E. S., and Terrones, M. E. (2005). Growth and volatility in an era of globalization. IMF Staff Papers, pages 31-63.

Backus, D. and Kehoe, P. (1992). International evidence on the historical properties of business cycles. American Economic Review, pages 864-888.

Badinger, H. (2010). Output volatility and economic growth. Economics Letters, 106(1):15-18.

Barro, R. J. (2001). Human capital and growth. The American Economic Review, 91(2):12-17.

Barro, R. J. and Lee, J.-W. (1994). Sources of economic growth. Carnegie-Rochester Conference Series on Public Policy, 40(0):1 - 46.

Canton, E. (2002). Business cycles in a two-sector model of endogenous growth. Economic Theory, 19(3):477-492.

Caporale, T. and McKiernan, B. (1998). The Fischer Black hypothesis: Some time-series evidence. Southern Economic Journal, 64(3):765-771. 
Cohen-Cole, E. B., Durlauf, S. N., and Rondina, G. (2012). Nonlinearities in growth: From evidence to policy. Journal of Macroeconomics, 34(1):42-58.

Davidson, R. and MacKinnon, J. G. (2001). Estimation and inference in econometrics. OUP Catalogue.

Dawson, J. W. and Stephenson, E. F. (1997). The link between volatility and growth: Evidence from the States. Economics Letters, 55(3):365-369.

Devereux, M. B. and Smith, G. W. (1994). International risk sharing and economic growth. International Economic Review, 35(3):pp. 535-550.

Döpke, J. (2004). How robust is the empirical link between business-cycle volatility and long-run growth in OECD countries? International Review of Applied Economics, 18(1):103-121.

Durlauf, S., Johnson, P., and Temple, J. (2005). Growth econometrics. Handbook of Economic Growth, 1:555-677.

Furceri, D. (2010). Long-run growth and volatility: Which source really matters? Applied Economics, 42(15):1865-1874.

Henderson, D. J., Papageorgiou, C., and Parmeter, C. F. (2012). Who benefits from financial development? New methods, new evidence. Working Paper.

Imbs, J. (2002). Why the link between volatility and growth is both positive and negative. CEPR discussion paper.

Imbs, J. (2007). Growth and volatility. Journal of Monetary Economics, 54(7):1848-1862.

Jetter, M., Nikolsko-Rzhevskyy, A., and Smith, W. (2013). The effects of wage volatility on growth. Journal of Macroeconomics, forthcoming.

Klomp, J. and de Haan, J. (2009). Political institutions and economic volatility. European Journal of Political Economy, 25(3):311-326.

Koren, M. and Tenreyro, S. (2007). Volatility and development. The Quarterly Journal of Economics, 122(1):243-287. 
Levine, R. and Renelt, D. (1992). A sensitivity analysis of cross-country growth regressions. American Economic Review, 82(4):942-963.

Martin, P. and Ann Rogers, C. (2000). Long-term growth and short-term economic instability. European Economic Review, 44(2):359-381.

Mills, T. C. (2000). Business cycle volatility and economic growth: A reassessment. Journal of Post Keynesian Economics, 23(1):107-116.

Mirestean, A. and Tsangarides, C. (2009). Growth Determinants Revisited, volume 9. International Monetary Fund.

Mirman, L. J. (1971). Uncertainty and optimal consumption decisions. Econometrica: Journal of the Econometric Society, pages 179-185.

Norrbin, S. C. and Pinar Yigit, F. (2005). The robustness of the link between volatility and growth of output. Review of World Economics, 141(2):343-356.

Oikawa, K. (2010). Uncertainty-driven growth. Journal of Economic Dynamics and Control, $34(5): 897-912$.

Posch, O. and Wälde, K. (2011). On the link between volatility and growth. Journal of Economic Growth, 16(4):285-308.

Ramey, G. and Ramey, V. A. (1995). Cross-country evidence on the link between volatility and growth. American Economic Review, 85(5):1138-51.

Ravn, M. O. and Uhlig, H. (2002). On adjusting the Hodrick-Prescott filter for the frequency of observations. Review of Economics and Statistics, 84(2):371-376.

Reinhart, C. M. and Rogoff, K. S. (2010). Growth in a time of debt. American Economic Review, 100(2):573-578.

Rodrik, D. (1998). Why do more open economies have bigger governments? Journal of Political Economy, 106(5):pp. 997-1032.

Shelton, C. (2007). The size and composition of government expenditure. Journal of Public Economics, 91(11):2230-2260. 
Temple, J. (1999). The new growth evidence. Journal of Economic Literature, 37(1):112-156.

Wang, P.-f. and Wen, Y. (2011). Volatility, growth, and welfare. Journal of Economic Dynamics and Control, 35(10):1696-1709.

Watson, M. (2007). How accurate are real-time estimates of output trends and gaps? FRB Richmond Economic Quarterly, 93(2):143-161. 


\section{Figures}

Avg. volatility worldwide

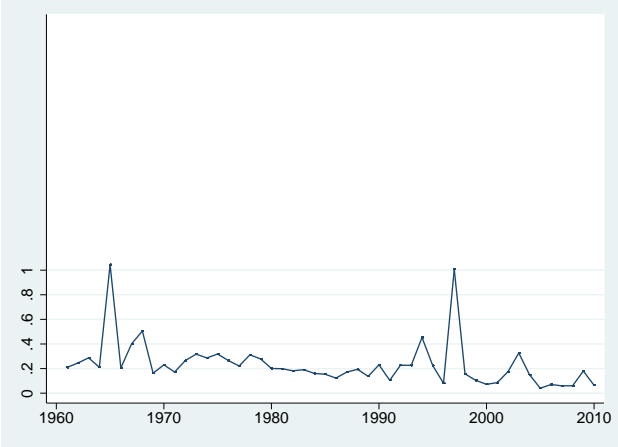

Avg. volatility

Asia \& Oceania

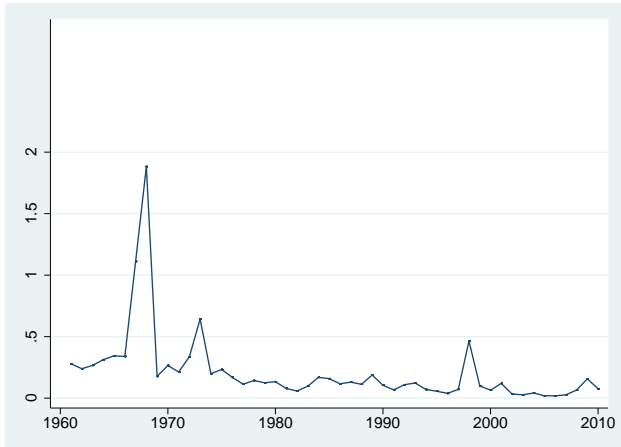

Avg. volatility

North America

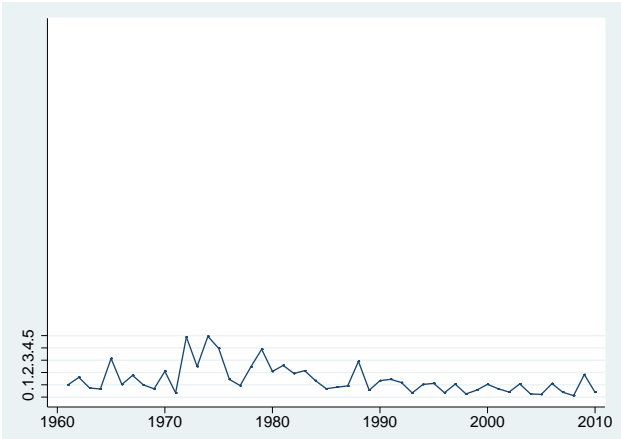

Avg. volatility Africa

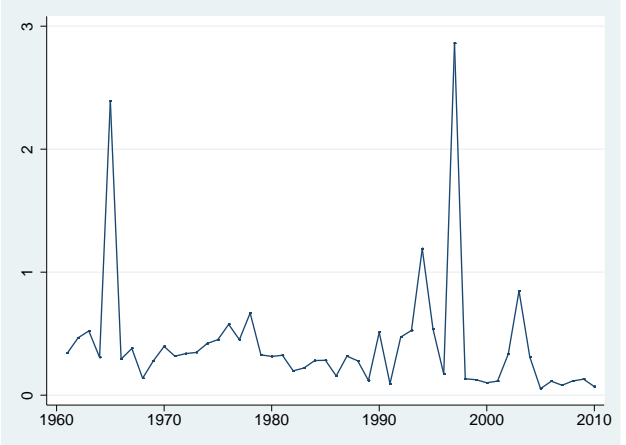

Avg. volatility

Europe

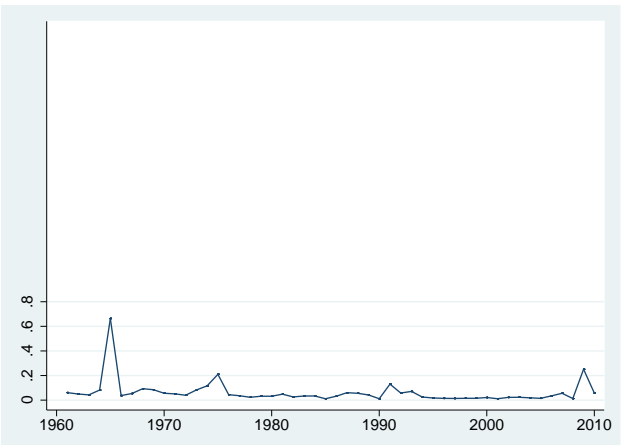

Avg. volatility South \& Middle America

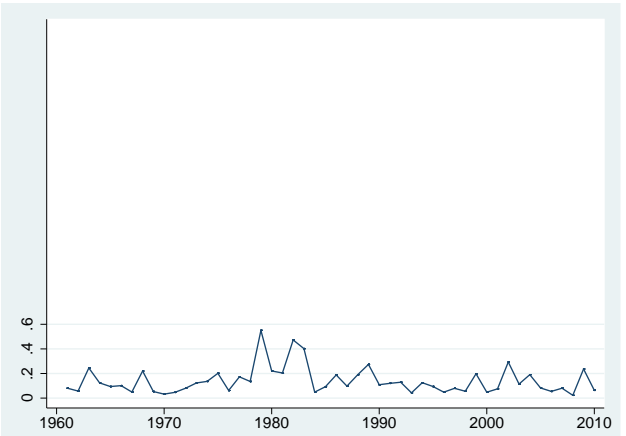

Figure 1: Average volatility over time

Notes: $\mathrm{x}$-axis $=$ year, $\mathrm{y}$-axis $=$ average volatility $(\mathrm{vol})$. 
1965

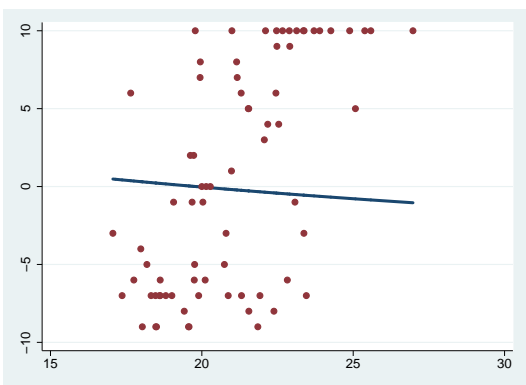

1995

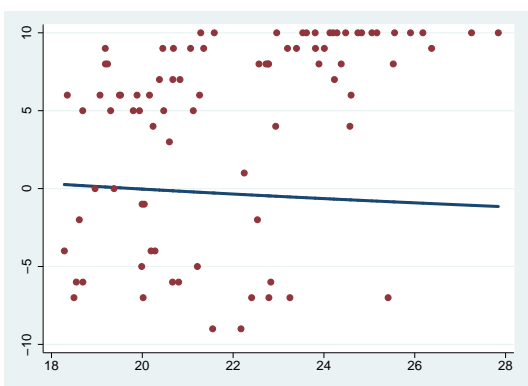

United States

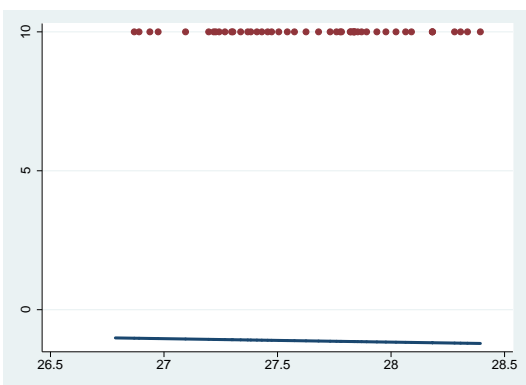

Thailand

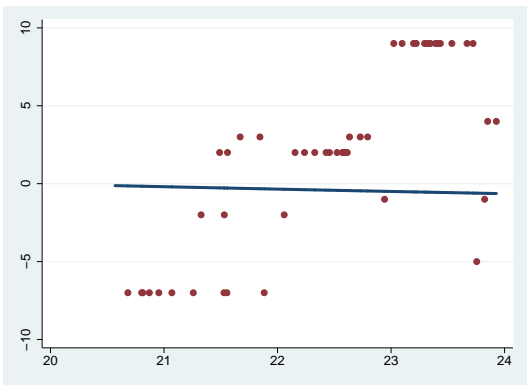

1975

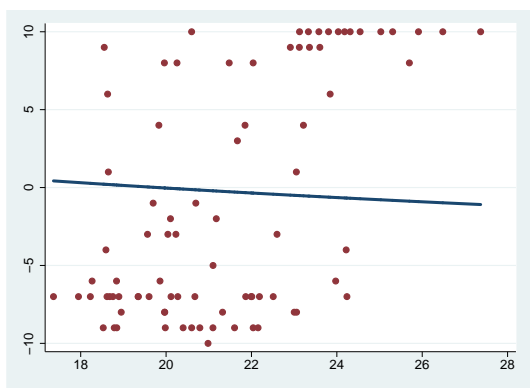

2005

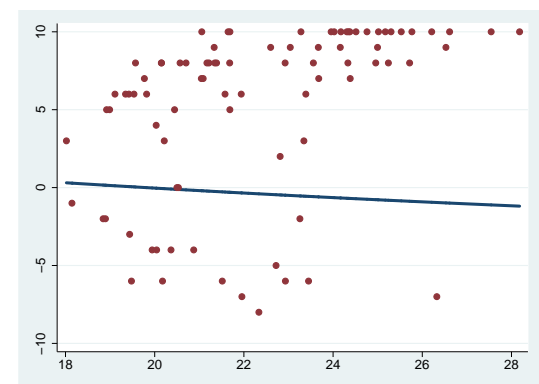

Spain

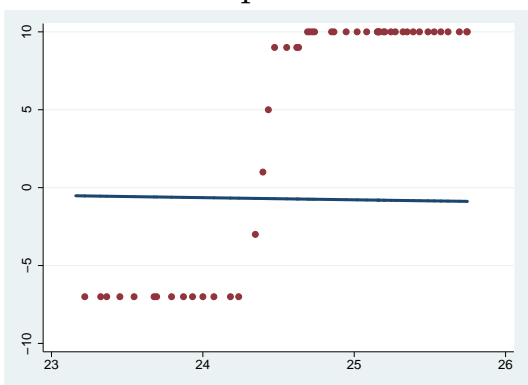

Ghana

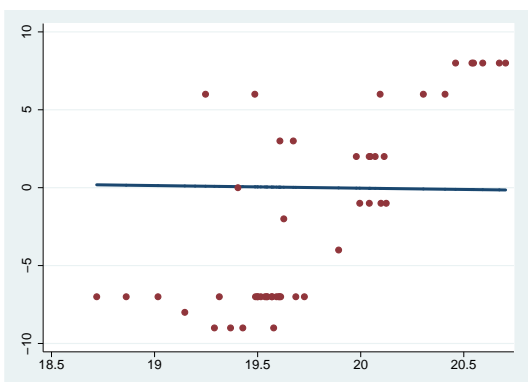

1985

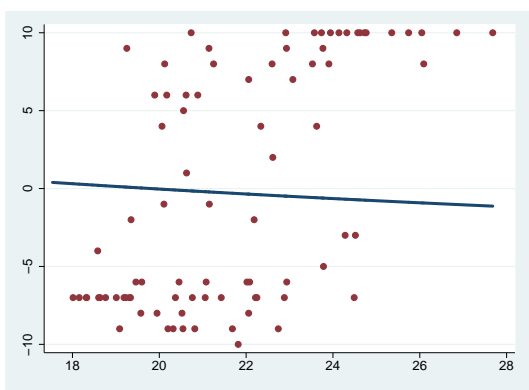

2010

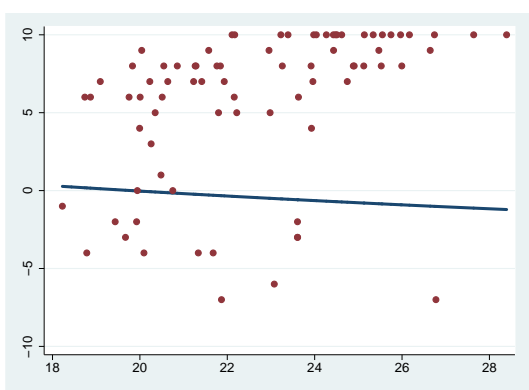

Brazil

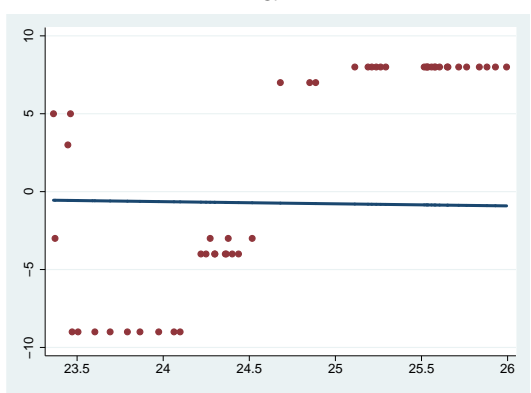

Oman

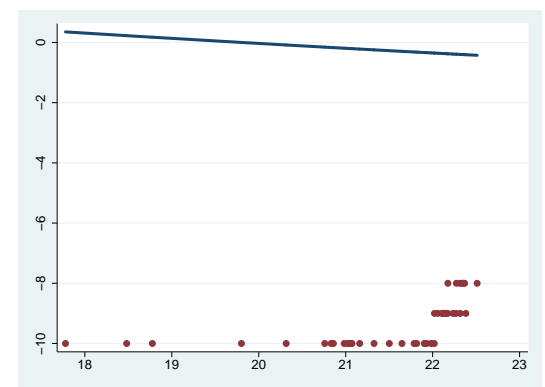

Figure 2: Net effects from volatility on growth

Notes: $\mathrm{x}$-axis $=$ government size $($ lngov), $\mathrm{y}$-axis = Polity IV (polity). Values over (under) the solid line represent observations where volatility ( $\mathrm{vol}$ ) is predicted to have decreased

(increased) economic growth. 


\section{Tables}

Table 1: Summary statistics

\begin{tabular}{|c|c|c|c|c|c|}
\hline Variable & Mean & Std. Dev. & $\mathbf{N}$ & Source & Description \\
\hline gr & 3.98 & 5.83 & 4,750 & WDI & GDP growth in annual $\%$ \\
\hline vol & 0.238 & 1.87 & 4,750 & own & $\begin{array}{l}\text { using the Hodrick-Prescott filter } \\
\text { with } \lambda_{H P}=100 \text { for detrending }\end{array}$ \\
\hline lngov & 21.59 & 2.35 & 4,470 & WDI & $\ln (\mathrm{GDP} *$ government share $/ 100)$ \\
\hline $\operatorname{lninv}$ & 21.86 & 2.50 & 4,668 & PWT 7.1 & $\ln (\mathrm{GDP} *$ investment share $/ 100)$ \\
\hline $\operatorname{lngdp}$ & 23.46 & 2.31 & 4,750 & WDI & $\ln ($ total GDP in constant $2000 \mathrm{US} \$)$ \\
\hline popgr & 0.02 & 0.022 & 4,750 & PWT 7.1 & $\frac{p_{o p}-p_{t} p_{t-1}}{p_{0} p_{t}}$ \\
\hline lnopen & 4.02 & 0.63 & 4,530 & WDI & $\ln ($ trade as $\%$ of GDP $)$ \\
\hline $\operatorname{lnlife}$ & 4.11 & 0.20 & 4,671 & WDI & $\ln ($ life expectancy at birth $)$ \\
\hline $\operatorname{lninfl}$ & 0.12 & 0.29 & 4,750 & WDI & $\ln [1+($ annual inflation/100) $]$ \\
\hline $\operatorname{lnpop}$ & 15.91 & 1.85 & 4,750 & WDI & $\ln$ (total population) \\
\hline polity & 1.73 & 7.24 & 4,279 & Polity IV & $\begin{array}{l}\text { variable polity } 2 \text {, ranging from }-10 \\
\text { (totally autocratic) to }+10 \text { (total } \\
\text { democracy) }\end{array}$ \\
\hline $\mathrm{vol}_{\lambda=6.25}$ & 0.17 & 1.23 & 4,750 & own & $\begin{array}{l}\text { using the Hodrick-Prescott filter } \\
\text { with } \lambda_{H P}=6.25 \text { for detrending }\end{array}$ \\
\hline g & 14.99 & 6.22 & 4,470 & WDI & government share of GDP \\
\hline inv & 21.73 & 9.76 & 4,669 & PWT 7.1 & investment share of GDP \\
\hline
\end{tabular}

Notes: WDI = World Development Indicators (World Bank). PWT 7.1 = Penn World Table Version 7.1. 
Table 2: Countries by average volatility (hpcyclesq) from 1960 - 2010.

\begin{tabular}{|c|c|c|c|}
\hline Country & Average Volatility & Country & Average Volatility \\
\hline \multicolumn{2}{|l|}{ Africa } & \multicolumn{2}{|l|}{ Europe } \\
\hline South Africa & 0.039 & France & 0.018 \\
\hline Egypt, Arab Rep. & 0.061 & Norway & 0.020 \\
\hline Benin & 0.080 & Austria & 0.024 \\
\hline Burkina Faso & 0.092 & Belgium & 0.026 \\
\hline Senegal & 0.126 & Spain & 0.028 \\
\hline Ghana & 0.129 & Netherlands & 0.030 \\
\hline Central African Republic & 0.137 & Italy & 0.033 \\
\hline Botswana & 0.150 & Sweden & 0.034 \\
\hline Madagascar & 0.158 & United Kingdom & 0.035 \\
\hline Cote d'Ivoire & 0.173 & Denmark & 0.041 \\
\hline Zambia & 0.174 & Portugal & 0.072 \\
\hline Morocco & 0.182 & Greece & 0.073 \\
\hline Kenya & 0.182 & Finland & 0.073 \\
\hline Cameroon & 0.210 & Luxembourg & 0.091 \\
\hline Congo, Dem. Rep. & 0.232 & Iceland & 0.123 \\
\hline Congo, Rep. & 0.242 & Hungary & 0.282 \\
\hline Malawi & 0.246 & & \\
\hline Sudan & 0.249 & \multicolumn{2}{|l|}{ Oceania } \\
\hline Burundi & 0.272 & Australia & 0.025 \\
\hline Togo & 0.295 & Papua New Guinea & 0.149 \\
\hline Niger & 0.298 & Fiji & 0.176 \\
\hline Zimbabwe & 0.327 & \multicolumn{2}{|c|}{ North America } \\
\hline Mauritania & 0.335 & Canada & 0.032 \\
\hline Sierra Leone & 0.339 & United States & 0.038 \\
\hline Lesotho & 0.386 & Puerto Rico & 0.051 \\
\hline Nigeria & 0.414 & Honduras & 0.080 \\
\hline Algeria & 0.531 & Mexico & 0.095 \\
\hline Chad & 0.621 & Bermuda & 0.105 \\
\hline Gabon & 0.774 & Trinidad and Tobago & 0.112 \\
\hline Rwanda & 1.033 & Belize & 0.129 \\
\hline Seychelles & 1.947 & Panama & 0.132 \\
\hline Liberia & 3.112 & Dominican Republic & 0.238 \\
\hline \multicolumn{2}{|l|}{ Asia } & St. Vincent and the Grenadines & 0.353 \\
\hline Sri Lanka & 0.031 & Bahamas, The & 0.371 \\
\hline Pakistan & 0.042 & \multicolumn{2}{|c|}{ South America } \\
\hline Japan & 0.060 & Guatemala & 0.031 \\
\hline Philippines & 0.065 & Colombia & 0.034 \\
\hline Nepal & 0.066 & Costa Rica & 0.083 \\
\hline India & 0.077 & Bolivia & 0.087 \\
\hline Israel & 0.093 & Ecuador & 0.087 \\
\hline Korea, Rep. & 0.096 & El Salvador & 0.090 \\
\hline Thailand & 0.097 & Brazil & 0.098 \\
\hline Malaysia & 0.099 & Paraguay & 0.109 \\
\hline Indonesia & 0.102 & Uruguay & 0.154 \\
\hline Bangladesh & 0.121 & Chile & 0.174 \\
\hline Singapore & 0.137 & Guyana & 0.190 \\
\hline Turkey & 0.143 & Peru & 0.199 \\
\hline China & 0.354 & Venezuela, RB & 0.240 \\
\hline Syrian Arab Republic & 0.543 & Nicaragua & 0.267 \\
\hline Oman & 1.772 & Argentina & 0.286 \\
\hline & & 18 & \\
\hline
\end{tabular}


Table 3: Basic OLS results

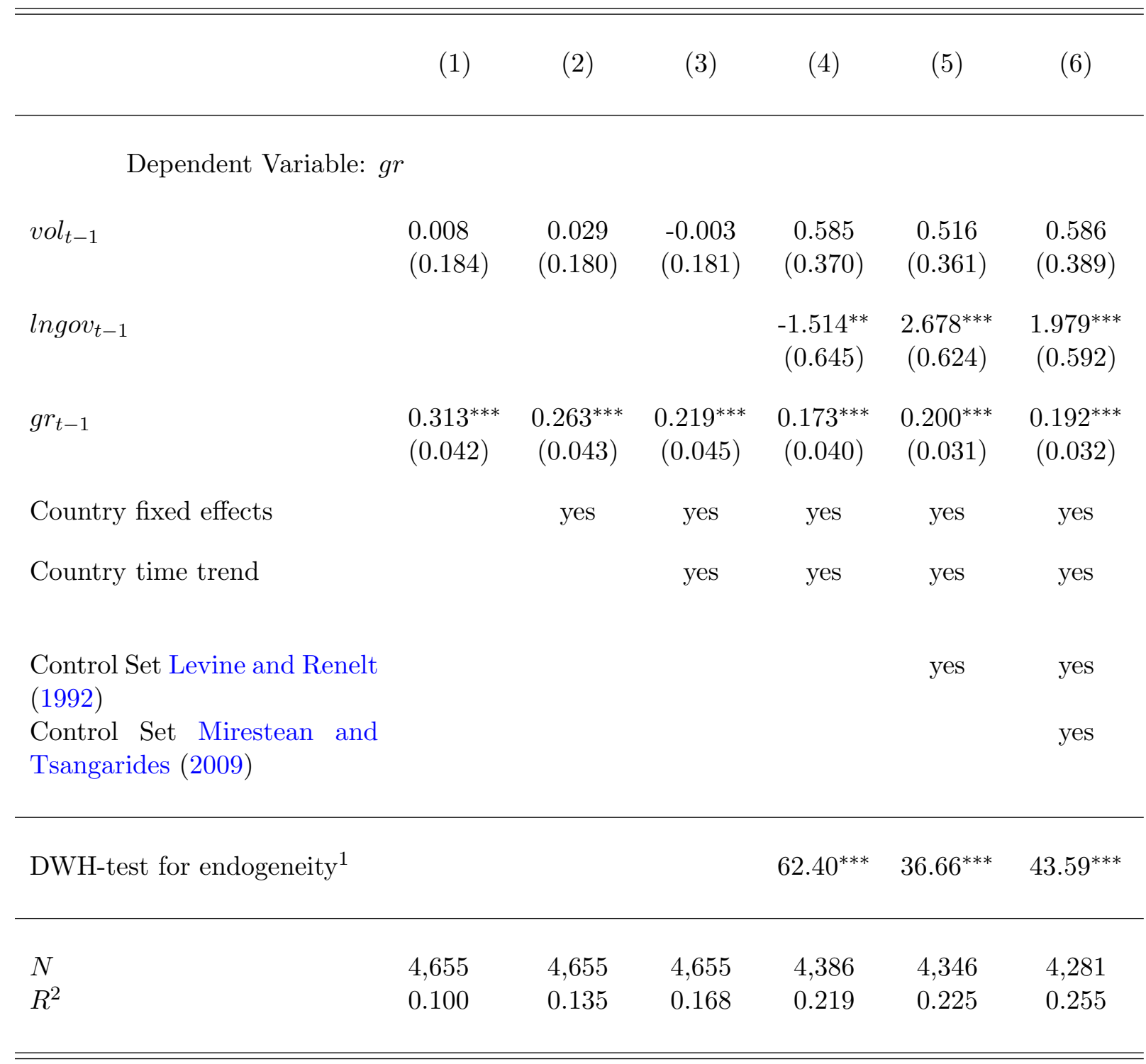

Notes: Standard errors in parentheses. ${ }^{*} p<0.10,{ }^{* *} p<0.05,{ }^{* * *} p<0.01$.

Control Set Levine and Renelt (1992): investment $\left(\right.$ lninv $\left._{t-1}\right)$, GDP $\left(\operatorname{lng}_{\mathrm{f}} p_{t-1}\right)$, population growth (popgr $\left.r_{t-1}\right)$. Control Set Mirestean and Tsangarides (2009): GDP (lngdpt-1), life expectancy (lnlife $\left.e_{t-1}\right)$, population growth $\left(\right.$ popgr $\left._{t-1}\right)$, openness to trade $\left(\operatorname{lnopen}_{t-1}\right)$, inflation $\left(\operatorname{lninf}_{t-1}\right)$.

${ }^{1}$ Testing for the endogeneity of government size, where the government size equation contains $\operatorname{lngov}_{i, t-1}$, lnopen $_{i, t-1}, \operatorname{lng} p_{i, t-1}, \operatorname{lnpop}_{i, t-1}$, country fixed effects, and country specific time trends. 
Table 4: OLS results, distinguishing by level of democracy/autocracy

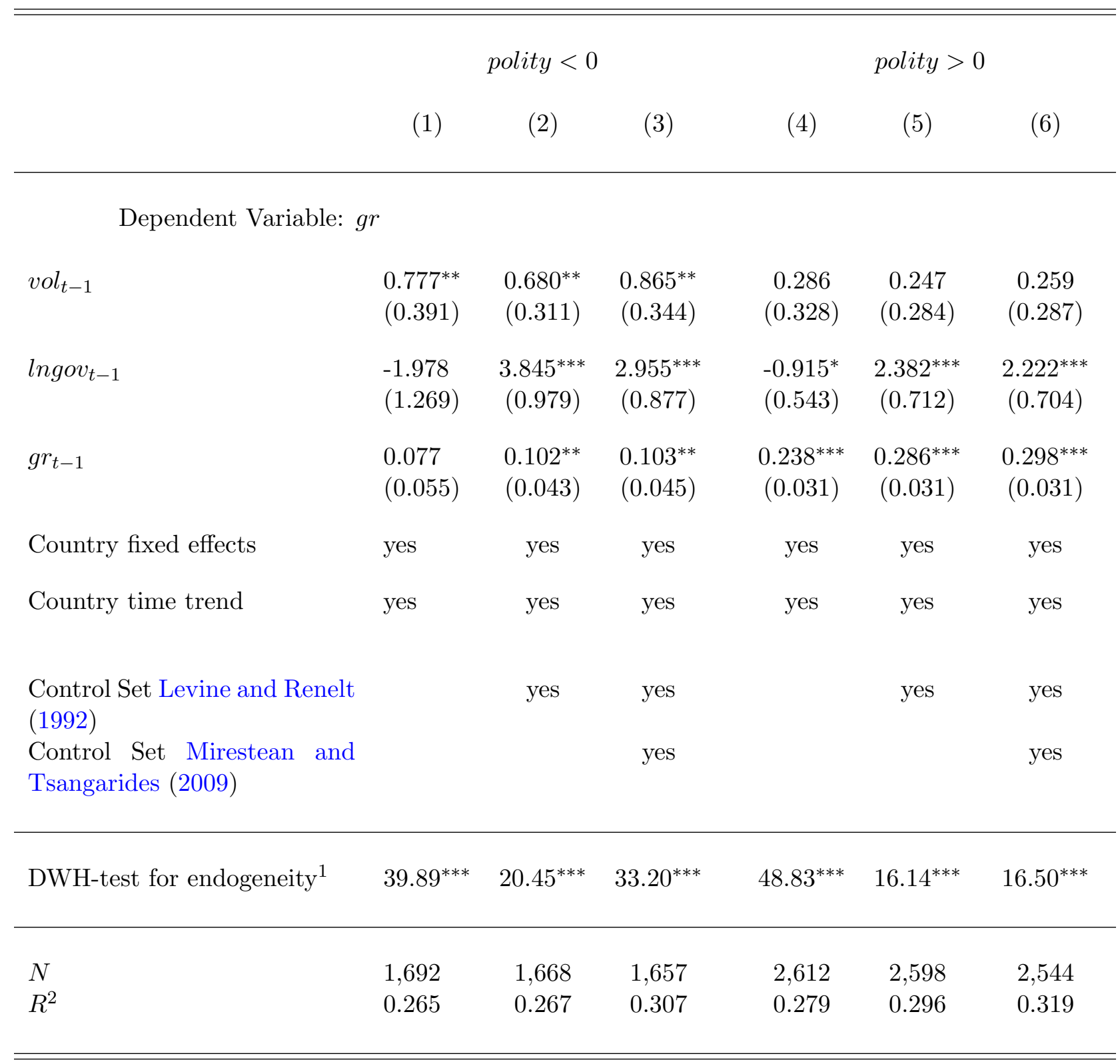

Notes: Standard errors in parentheses. ${ }^{*} p<0.10,{ }^{* *} p<0.05,{ }^{* * *} p<0.01$

Control Set Levine and Renelt (1992): investment $\left(\operatorname{lninv}_{t-1}\right)$, GDP (lngdpt-1), and population growth (popgr $\left.r_{t-1}\right)$.

Control Set Mirestean and Tsangarides (2009): GDP (lngdpt-1), life expectancy (lnlife $\left.e_{t-1}\right)$,

population growth $\left(\right.$ popgr $\left._{t-1}\right)$, openness to trade $\left(\right.$ lnopen $\left._{t-1}\right)$, and inflation $\left(\operatorname{lninfl}_{t-1}\right)$. 
Table 5: 3SLS results

\begin{tabular}{|c|c|c|c|c|c|}
\hline & \multicolumn{2}{|c|}{ Full sample } & \multirow{2}{*}{$\begin{array}{c}\text { polity }<0 \\
(3)\end{array}$} & \multirow{2}{*}{$\begin{array}{c}\text { polity }>0 \\
\text { (4) }\end{array}$} & \multirow{2}{*}{$\begin{array}{l}\text { Full sample } \\
\qquad(5)\end{array}$} \\
\hline & $(1)$ & $(2)$ & & & \\
\hline \multicolumn{6}{|l|}{ Dependent Variable: $g r$} \\
\hline $\operatorname{vol}_{t-1}$ & $\begin{array}{c}0.587^{* * *} \\
(0.100)\end{array}$ & $\begin{array}{c}0.603^{* * *} \\
(0.100)\end{array}$ & $\begin{array}{c}0.897^{* * *} \\
(0.145)\end{array}$ & $\begin{array}{c}0.211 \\
(0.177)\end{array}$ & $\begin{array}{c}0.329^{* *} \\
(0.141)\end{array}$ \\
\hline $\operatorname{lngov}_{t}$ & $\begin{array}{c}-0.929^{* *} \\
(0.438)\end{array}$ & $\begin{array}{c}-1.236^{* * *} \\
(0.438)\end{array}$ & $\begin{array}{c}-1.623^{*} \\
(0.913)\end{array}$ & $\begin{array}{c}-1.590^{* *} \\
(0.630)\end{array}$ & $\begin{array}{c}-1.439^{* * *} \\
(0.454)\end{array}$ \\
\hline$g r_{t-1}$ & $\begin{array}{c}0.173^{* * *} \\
(0.015)\end{array}$ & $\begin{array}{c}0.169^{* * *} \\
(0.015)\end{array}$ & $\begin{array}{c}0.087^{* * *} \\
(0.024)\end{array}$ & $\begin{array}{c}0.280^{* * *} \\
(0.020)\end{array}$ & $\begin{array}{c}0.142^{\text {*** }} \\
(0.016)\end{array}$ \\
\hline vol $_{t-1} \times$ polity $_{t-1}$ & & & & & $\begin{array}{c}-0.074^{* * *} \\
(0.023)\end{array}$ \\
\hline polity $_{t-1}$ & & & & & $\begin{array}{c}0.022 \\
(0.022)\end{array}$ \\
\hline Country fixed effects \& time trends & yes & yes & yes & yes & yes \\
\hline $\begin{array}{l}\text { Control Sets Levine and Renelt } \\
\text { (1992) and Mirestean and Tsan- } \\
\text { garides (2009) }\end{array}$ & yes & yes & yes & yes & yes \\
\hline \multicolumn{6}{|l|}{ Dependent Variable: lngov } \\
\hline $\operatorname{vol}_{t-1}$ & $\begin{array}{c}0.006^{* *} \\
(0.003)\end{array}$ & $\begin{array}{c}0.006^{* *} \\
(0.003)\end{array}$ & $\begin{array}{l}-0.001 \\
(0.004)\end{array}$ & $\begin{array}{c}0.012^{* *} \\
(0.005)\end{array}$ & $\begin{array}{c}0.012^{\text {*** }} \\
(0.004)\end{array}$ \\
\hline$g r_{t}$ & $\begin{array}{c}0.004^{* * *} \\
(0.001)\end{array}$ & $\begin{array}{c}0.013^{* * *} \\
(0.002)\end{array}$ & $\begin{array}{c}0.012^{* * *} \\
(0.003)\end{array}$ & $\begin{array}{c}0.006^{* * *} \\
(0.002)\end{array}$ & $\begin{array}{c}0.014^{* * *} \\
(0.002)\end{array}$ \\
\hline $\operatorname{lngov}_{t-1}$ & $\begin{array}{c}0.868^{* * *} \\
(0.008)\end{array}$ & $\begin{array}{c}0.795^{* * *} \\
(0.010)\end{array}$ & $\begin{array}{c}0.728^{* * *} \\
(0.017)\end{array}$ & $\begin{array}{c}0.735^{* * *} \\
(0.013)\end{array}$ & $\begin{array}{c}0.792^{\text {*** }} \\
(0.010)\end{array}$ \\
\hline vol $_{t-1} \times$ polity $_{t-1}$ & & & & & $\begin{array}{c}0.002^{* *} \\
(0.001)\end{array}$ \\
\hline polity $_{t-1}$ & & & & & $\begin{array}{c}-0.001 \\
(0.001)\end{array}$ \\
\hline Country fixed effects \& time trends & yes & yes & yes & yes & yes \\
\hline Control Set Shelton (2007) & & yes & yes & yes & yes \\
\hline$N$ & 4,266 & 4,266 & 1,651 & 2,536 & 3,974 \\
\hline
\end{tabular}

Notes: Standard errors in parentheses. ${ }^{*} p<0.10,{ }^{* *} p<0.05,{ }^{* * *} p<0.01$. Control Set Levine and Renelt (1992): investment $\left(\operatorname{lninv} v_{t-1}\right)$, GDP $\left(\ln g d p_{t-1}\right)$, and population growth $\left(\right.$ popgr $\left._{t-1}\right)$. Control Set Mirestean and Tsangarides (2009): GDP $\left(\operatorname{lng} d p_{t-1}\right)$, life expectancy $\left(\operatorname{lnlife}_{t-1}\right)$, population growth $\left(\right.$ popgr $\left._{t-1}\right)$, openness to trade $\left(\operatorname{lnopen}_{t-1}\right)$, and inflation $\left(\operatorname{lninf} l_{t-1}\right)$. Control Set Shelton (2007): GDP $\left(\operatorname{lng} g p_{t-1}\right)$, openness to trade $\left(\right.$ lnopen $\left._{t-1}\right)$, and population size $\left(\operatorname{lnpop}_{t-1}\right)$. 
Table 6: Robustness checks

\begin{tabular}{|c|c|c|c|c|c|c|}
\hline & \multicolumn{2}{|c|}{$\lambda_{H P}=6.25$} & \multicolumn{2}{|c|}{$1965-2005$} & \multicolumn{2}{|c|}{ Using shares } \\
\hline & (1) & $(2)$ & $(3)$ & $(4)$ & $(5)$ & (6) \\
\hline \multicolumn{7}{|l|}{ Dependent Variable: $g r$} \\
\hline $\operatorname{vol}_{t-1}$ & $\begin{array}{l}0.008^{* * *} \\
(0.001)\end{array}$ & $\begin{array}{c}0.003 \\
(0.002)\end{array}$ & $\begin{array}{c}0.725^{* * *} \\
(0.108)\end{array}$ & $\begin{array}{c}0.375^{* *} \\
(0.157)\end{array}$ & $\begin{array}{c}0.572^{* * *} \\
(0.078)\end{array}$ & $\begin{array}{c}0.281^{* *} \\
(0.139)\end{array}$ \\
\hline $\operatorname{lngov}_{t-1}$ & $\begin{array}{l}-1.261^{* * *} \\
(0.438)\end{array}$ & $\begin{array}{c}-1.484^{* * *} \\
(0.455)\end{array}$ & $\begin{array}{c}-2.446^{* * *} \\
(0.533)\end{array}$ & $\begin{array}{c}-2.694^{* * *} \\
(0.551)\end{array}$ & $\begin{array}{c}-0.111^{* * *} \\
(0.029)\end{array}$ & $\begin{array}{c}-0.122^{* * *} \\
(0.029)\end{array}$ \\
\hline$g r_{t-1}$ & $\begin{array}{l}0.167^{* * *} \\
(0.015)\end{array}$ & $\begin{array}{c}0.140^{* * *} \\
(0.016)\end{array}$ & $\begin{array}{c}0.181^{* * *} \\
(0.017)\end{array}$ & $\begin{array}{c}0.168^{* * *} \\
(0.017)\end{array}$ & $\begin{array}{c}0.174^{* * *} \\
(0.015)\end{array}$ & $\begin{array}{c}0.146^{* * *} \\
(0.016)\end{array}$ \\
\hline vol $_{t-1} \times$ polity $_{t-1}$ & & $\begin{array}{c}-0.001^{* * *} \\
(0.000)\end{array}$ & & $\begin{array}{c}-0.001^{* * *} \\
(0.000)\end{array}$ & & $\begin{array}{c}-0.045^{* *} \\
(0.018)\end{array}$ \\
\hline polity $_{t-1}$ & & $\begin{array}{l}0.043^{* *} \\
(0.022)\end{array}$ & & $\begin{array}{c}0.053^{* *} \\
(0.025)\end{array}$ & & $\begin{array}{c}0.032 \\
(0.022)\end{array}$ \\
\hline Country fixed effects \& time trends & yes & yes & yes & yes & yes & yes \\
\hline $\begin{array}{l}\text { Control Sets Levine and Renelt } \\
\text { (1992) and Mirestean and Tsan- } \\
\text { garides (2009) }\end{array}$ & yes & yes & yes & yes & yes & yes \\
\hline \multicolumn{7}{|l|}{ Dependent Variable: lngov } \\
\hline $\operatorname{vol}_{t-1}$ & $\begin{array}{l}0.000^{*} \\
(0.000)\end{array}$ & $\begin{array}{l}0.000^{* *} \\
(0.000)\end{array}$ & $\begin{array}{l}0.006^{* *} \\
(0.003)\end{array}$ & $\begin{array}{c}0.015^{* * *} \\
(0.004)\end{array}$ & $\begin{array}{l}-0.050 \\
(0.033)\end{array}$ & $\begin{array}{c}0.064 \\
(0.055)\end{array}$ \\
\hline$g r_{t}$ & $\begin{array}{l}0.012^{* * *} \\
(0.002)\end{array}$ & $\begin{array}{c}0.014^{* * *} \\
(0.002)\end{array}$ & $\begin{array}{c}0.014^{* * *} \\
(0.002)\end{array}$ & $\begin{array}{c}0.015^{* * *} \\
(0.002)\end{array}$ & $\begin{array}{l}-0.021 \\
(0.024)\end{array}$ & $\begin{array}{c}0.008 \\
(0.028)\end{array}$ \\
\hline $\operatorname{lngov}_{t-1}$ & $\begin{array}{l}0.794^{* * *} \\
(0.010)\end{array}$ & $\begin{array}{c}0.791^{* * *} \\
(0.010)\end{array}$ & $\begin{array}{c}0.781^{* * *} \\
(0.012)\end{array}$ & $\begin{array}{c}0.781^{* * *} \\
(0.012)\end{array}$ & $\begin{array}{c}0.794^{* * *} \\
(0.009)\end{array}$ & $\begin{array}{c}0.795^{* * *} \\
(0.010)\end{array}$ \\
\hline vol $_{t-1} \times$ polity $_{t-1}$ & & $\begin{array}{c}0.000 \\
(0.000)\end{array}$ & & $\begin{array}{c}0.000^{* * *} \\
(0.000)\end{array}$ & & $\begin{array}{c}0.021^{* * *} \\
(0.008)\end{array}$ \\
\hline polity $_{t-1}$ & & $\begin{array}{l}-0.001 \\
(0.001)\end{array}$ & & $\begin{array}{c}-0.001^{*} \\
(0.001)\end{array}$ & & $\begin{array}{l}-0.016^{*} \\
(0.009)\end{array}$ \\
\hline Country fixed effects \& time trends & yes & yes & yes & yes & yes & yes \\
\hline Control Set Shelton (2007) & yes & yes & yes & yes & yes & yes \\
\hline$N$ & 4,266 & 3,974 & 3,531 & 3,314 & 4,306 & 4,009 \\
\hline
\end{tabular}

Notes: Standard errors in parentheses. ${ }^{*} p<0.10,{ }^{* *} p<0.05,{ }^{* * *} p<0.01$. Control Set Levine and Renelt (1992): investment, GDP, and population growth. Control Set Mirestean and Tsangarides (2009): GDP, life expectancy, population growth, openness to trade, and inflation.

Control Set Shelton (2007): GDP, openness to trade, and population size. 